\title{
Some Morphological and Molecular Aspects of the Life Cycle of Trypansoma cruzi in the Insect Vector
}

\begin{abstract}
Rodrigo Zeledón
Programa de Investigación en Enfermedades Tropicales, Escuela de Medicina Veterinaria, Universidad Nacional, Heredia, Costa Rica
\end{abstract}

Key words: life cycle - Trypanosoma cruzi - insect - vetor

On two occasions I have reviewed the different aspects of the life cycle of Trypanosoma cruzi in the insect vector. In the first article (Zeledón 1987) I presented a detailed historical appraisal of the subject since the pioneer work done by Carlos Chagas and some years later by Emmanuel Dias in Brazil, through the more recent contributions on the subject. I also discussed some aspects of the host-parasite relationships, including the different factors involved in the cycle. In the second review article (Zeledón 1997), I stressed the microecological factors implicated in the cycle, particularly the role played by cyclic adenosine monophosphate (c AMP), a molecule which seems to be a clue in the metacyclogenesis process of the parasite. I also emphasized the importance of the morphological studies made by us and by others with both transmission and scanning electron microscopy in order to shed light on some of the key aspects of the cycle.

In referring to the so called extraintestinal or hemocele cycle of the parasite in the insect we suggested, for the first time in the later review, that some of the forms described by Lacombe (1980), as part of this cycle, could belong to the same microsporidian previously described by Kramer (1972) as Octosporea carloschagasi. The description of this new species by Kramer was based on some of the forms observed by Chagas in the gut of Panstrongylus megistus which were confused by him, and 70 years later by Lacombe, with morphological stages of the life cycle of $T$. cruzi in the insect. In some of Chagas' figures, Kramer recognized schizonts, sporonts and spores of the new microsporidian (see Plate 12, figs 83-85 and figs 89-97 of Chagas original paper).

Fax: +506-253.633. E-mail: rzeledon@ sol.racsa.co.cr Received 9 June 1999

Accepted 9 August 1999
I now believe that the intracellular forms and the spheres described in some detail by Lacombe $(1980,1981 a, b)$ in the hemocytes and the cells of the Malphigian tubes, represent at least part of the schizogonic and sporogonic cycles of $O$. carloschagasi, which were also observed in Triatoma infestans and apparently in other species of triatomines (see for instance figs 21, 22 of Lacombe 1980 and fig. 6 of Lacombe \& Santos 1984).

In relation to other factors involved in the cycle, some information about the population density of the different morphological stages present in various parts of the intestine of the insect, under certain physiological conditions or time periods, have been published recently (Kollien \& Schaub 1997, 1998a, b). Kollien et al. (1998), also confirmed that the flagellates have no tendency to attach themselves by the flagellum to the wall of the midgut as they do in the hindgut. This group of authors also claim that the rectal cuticle of the insect consists of a superficial wax layer (hydrophobic layer) where the flagella of the parasites can attach by electrostatic forces as occurs in vitro (Kleffmann et al. 1998, Schmidt et al. 1998). This would contradict the hypothesis of a more specific type of attachment by hemidesmosomes like structures or by polypeptides as discussed previously (Zeledón 1997).

\section{REFERENCES}

Chagas C 1909. Nova tripanosomiaze humana. Estudos sobre a morfolojía e o ciclo evolutivo do Schizotrypanum cruzi n. gen., n. sp., ajente etiolojico de nova entidade morbida do homen. Mem Inst Oswaldo Cruz 1: 159-218.

Kleffmann T, Schmidt J, Schaub GA 1998. Attachment of Trypansoma cruzi epimastigotes to hydrophobic substrates and use of this property to separate stages and promote metacyclogenesis. J Euk Microbiol 45: 548-555.

Kollien AH, Schaub GA 1997. Trypanosoma cruzi in the rectum of the bug Triatoma infestans: effects of blood ingestion of the vector and artificial diuresis. Parasitol Res 83: 781-788.

Kollien AH, Schaub GA 1998a. Trypanosoma cruzi in the rectum of the bug Triatoma infestans: effects of 
blood ingestion by the starved vector. Am J Trop Med Hyg 59: 166-170.

Kollien AH, Schaub GA 1998b. The development of Trypanosoma cruzi (Trypanosomatidae) in the reduviid bug Triatoma infestans (Insecta): influence of starvation. J Euk Microbiol 45: 59-63.

Kollien AH, Schmidt J, Schaub GA 1998. Modes of association of Trypanosoma cruzi with the intestinal tract of the vector Triatoma infestans. Acta Trop 70: 127-141.

Kramer JP 1972. Octosporea carloschagasi n. sp. a microsporidian associate of Trypansoma cruzi in Panstrongylus megistus. Z Parasitenk 39: 221-224.

Lacombe D 1980. Fase extra-intestinal do ciclo evolutivo do Trypansoma cruzi em Triatoma infetans. Rev Brasil Biol 40: 525-535.

Lacombe D 1981a. Ciclo extra-intestinal do Trypanosoma cruzi em especies dos gêneros Panstrongylus, Rhodnius e Triatoma. Rev Brasil Biol 41: 521-528. Lacombe D 1981b. Development of Trypanosoma cruzi in ampullae of Malpighian tubes. An Acad Brasil Cienc 53: 206.

Lacombe D, Santos JR dos 1984. The development of extra-intestinal cycle of Trypansoma cruzi in Triatoma infestans and Panstrongylus megistus. An Acad Brasil Cienc 56: 221-230.

Schmidt J, Keffmann T, Schaub GA 1998. Hydrophobic attachment of Trypansoma cruzi to a superficial layer of the rectal cuticle in the bug Triatoma infestans. Parasitol Res 84: 527-536.

Zeledón R 1987. Life cycle of Trypanosoma cruzi in the insect vector, p. 59-75. In RR Brenner \& AM Stoka (eds), Chagas Disease Vectors, Vol. II, Anatomic and Physiological Aspects, CRC Press Inc., Boca Raton, $\mathrm{Fl}$.

Zeledón R 1997. Infection of the insect host by Trypanosoma cruzi, p. 271-287. In RU Carcavallo, I Galíndez Girón, J Jurberg \& H Lent (eds), Atlas of Chagas Disease Vectos in the Americas, Vol. I, Fiocruz, Rio de Janeiro. 